Nama : Reza Ananda

Nim : 10200120231

Kelas : HTN F

Resume Jurnal

Judul : Partai Politik Lokal di Negara Kesatuan : Upaya Mewujudkan Otonomi Daerah di Bidang Politik

\title{
Pendahuluan :
}

Selama tiga puluh dua tahun berada di bawah rezim orde baru, Indonesia mengalami apa yang disebut oleh Karl D. Jason sebagai bereucratic politic (politikbirokrasi), yaitu suatu keadaan politik yang menempatkan negara pada kedudukan sangat dominan.Pada era ini, kekuasaan dalam pembuatan keputusan didominir para penguasa, terutama para perwira militer dan pejabat tinggi birokrasi.

Keadaan demikian dalam teori korporatisme sebagaimana pernah ditulis oleh Moh.Mahfud MD, negara dipandang sebagai suatu organ yang mempunyai kemauandan kepentingan sendiri yang dapat melakukan campur tangan dalam kehidupan masyarakatnya. Kerangka berfikir demikianlah ternyata yang menjadi pandangan penguasa orde baru. Kerangka berfikir tersebut dilatarbelakangi oleh keyakinanbahwa stabilitas politik adalah kunci utama dalam mengejar ketertinggalan darinegara-negara lain, terutama untuk memulai pertumbuhan ekonomi dengan cepat.

Setelah reformasi bergulir yang ditandai dengan lengsernya Soeharto dari kursikepresidenan, dilakukan berbagai ikhtiar perbaikan bangsa. Salah satu ikhtiarketatanegaraan yang dilakukan adalah dengan melakukan amandemen terhadapUndang-Undang Dasar (UUD) 1945. Sejak 1998 hingga 2001, terdapat empat kaliamandemen terhadap UUD 1945.

Dalam rangka menjalankan otonomi daerah tersebut, setiap daerah memilikikekuasaan dalam berbagai bidang, kecuali yang menjadi kekuasaan pemerintahpusat. Kekuasaan pemerintah pusat tersebut ditegaskan dalam Pasal 10 ayat (3) UUNomor 32 Tahun 2004, yaitu meliputi kekuasaan dalam bidang : a. politik luar negeri b. Pertahanan; c. Keamanan; $d$. Peradilan. e. Moneter dan fiskal, dan f. Agama.

Berdasarkan pembagian urusan pemerintahan sebagaimana diatur dalam UUNo. 32 Tahun 2004 di atas, maka salah satu otonomi yang dimiliki daerah ialahotonomi dalam bidang politik. Ikhtiar untuk mewujudkan otonomi di bidang politiktersebut dilakukan dengan 
memberi pengaturan baru tentang Pemilihan KepalaDaerah dan Wakil Kepala Daerah secara langsung, termasuk pengaturan tentangmekanisme pemilihan Anggota Legislatif, seperti DPRD (Provinsi, Kabupaten/Kota)dan DPD yang lebih mendekatkan pemilih dengan si calon yang merupakan wakildari daerahnya.

Dua mekanisme rekrutmen kepemimpinan daerah di atas secara simbolik menggambarkan telah hadirnya otonomi di bidang politik, karena dipilih langsungoleh penduduk daerah setempat. Otonomi politik itu sesungguhnya belum terwujud,sebab masih terbukanya kemungkinan pintu campur tangan terhadap otonomi politikdi daerah oleh pusat. Campur tangan itu hadir seiring dengan masih diterapkannyasistem kepartaian yang bersifat nasional. Akibatnya, partai politik di tingkat nasionalsering mengintervensi partaipartai politik di daerah dalam dua mekanismepemilihan tadi.

Hal inilah yang memunculkan gagasan untuk membentuk partai politik lokaldi setiap daerah, selain terdapat beberapa alasan lain yang relevan dikemukakandalam rangka mendukung gagasan pembentukan partai politik lokal ini, sepertiadanya pengalaman historis bangsa ini pada 1955. Partai politik lokal pernahdiperkenankan dan mengikuti pemilihan umum pada tahun itu.

Pada masa mendatang, gagasan mengenai pembentukan partai politik lokal dilndonesia sebagai konsekuensi dilaksanakannya otonomi daerah merupakan halyang perlu dipersiapkan sejak awal secara akademik. Penelitian ini bermaksud untukmelakukan analisis akademik terhadap dua hal. Pertama, kemungkinan lahirnyapartai politik lokal di Indonesia. Kedua, bagaimana konsep dasar partai politik lokaltersebut jika diimplementasikan dalam negara Republik Indonesia yang berbentukkesatuan

\section{Rumusan Masalah}

Berdasarkan latar belakang di atas, rumusan masalah dalam tulisan ini adalah,Pertama: apa urgensi melahirkan partai politik lokal di Indonesia yang berbentuknegara kesatuan? Kedua, bagaimanakah konsep partai politik lokal yang relevanditerapkan di Indonesia sebagai negara kesatuan?

\section{Metode Penelitian}

Dilakukan dengan cara meneliti, mempelajari dan menganalisis secara cermat terhadap bahan-bahan hukum primer dan sekunder diatas. Dalam tulisan ini, analisis bahan hukum dilakukan dengan menggunakanmetode kualitatif. Metode ini dimualai dengan data yang dihimpun dengan caradiuraikanan di atas, kemudian diolah dengan cara data diseleksi, diklasifikasikansecara sistematik, logik dan yuridis untuk mendapatkan gambaran umum untuk mendukung tulisan ini. 


\section{Pembahasan}

Konsep Dasar Federalisme

Menurut Preston King, bentuk negara federal dalam konsepnya seringdipertentangkan dengan teori kedaulatan. Teori kedaulatan sendiri dipopulerkanoleh Jean Bodin, Thomas Hobbes, Spinoza dan Austin. Bagi para penggagas konsepkedaulatan, ia adalah sesuatu yang bersifat asli, tertinggi dan tidak dapat dibagi-bagi. Dalam konteks hubungan antara pemerintahan pusat dengan daerah,kedaulatan hendaknya tidak terbagi-bagi, baik ia berada pada pemerintahan pusat,maupun daerah. Disinilah kritik terhadap konsep federal timbul oleh banyakkalangan.

Prodount, seorang pakar politik dari Perancis adalah orang yang pertama mengemukakan konsep federal ini. Secara teoritis, Istilah yang berhubungan denganfederalisme biasanya disebutkan dalam dua istilah, iaitu federalisme itu sendiri danfederal (federation). Friderich mengartikan federalisme sebagai satu kesatuan yangtetap menghargai perbedaan dalam kesatuan itu. la menyatakan: "Federalism as aunion groups, united by one or more common objectives, but retaining their distinctive group character for other purposes".

Bagi para pengikut pandangan federalisme ideologis, istilah federalisme ialahmerujuk pada bentuk federalisme sebagai sebuah ideologi. la merupakan sesuatuyang dikontruksikan sebagai sebuah doktrin. Alexander Marc mengatakan bahwa"federalism became a doctrine" pada abad kesembilan belas. Bahkan P.J. Prodhountsebagai peletak dasar teori-teori tentang federal menyatakan "truth is one" (percayapada idea persekutuan ini)". Kata truth menurut King diartikan Proudont bertujuanmenjadikan gagasannya tentang federalisme dapat dijadikan sebagai satu-satunyadoktrin dan kemudian dapat dirumuskan dalam Konstitusi-Konstitusi di pelbagainegara.

Bagi Prodount, gagasan tentang federalisme yang ditawarkannya masa itu lebihdiartikan sebagai nilai-nilai federalisme yang berisi pentingnya penghargaanterhadap daerahdaerah oleh pemerintah pusat. Prodount sebagai penemu teori federalisme tidak menyebut bahaa federalisme mesti dilakukan dengan membentuknegara federal. la mengatakan "the sole constitution which an astringent reason willcompel the peoples of the world to adopt is federalism".

Ajaran Federalisme di Negara Kesatuan

Secara teoritis, terdapat perbedaan antara devolusi kekuasaan denganpembagian kekuasaan dalam negara federal. Pembagian kekuasaan dalam negarafederal dicirikan dengan adanya pembagian kekuasaan antara pemerintah pusat dandaerah yang diatur 
secara tegas dalam Konstitusi. Devolusi kekuasaan memberikanpembagian kekuasaan antara pemerintah pusat dengan daerah melalui kebijakanyang diberikan oleh pemerintah pusat.

Sejarah berlakunya devolusi kekuasaan di Inggris dimulai dengan adanyakonflik antara pemerintah pusat Inggris dan beberapa daerah, seperti Scotlandia,Wales dan Irlandia Utara. Daerah-daerah tersebut merasa memiliki karakteristikyang khas dan berbeda dibanding kebanyakan daerah di Inggris lainnya. Perbedaanitulah yang dijadikan alasan untuk memisahkan diri dari Inggris.

Dalam konteks implementasi devolusi kekuasaan di Inggris, terdapat perbedaanmendasar antara istilah devolusi legislatif dan eksekutif. Devolusi kekuasaan legislatifdimaknai sebagai kekuasaan yang dimiliki pemerintah daerah (provinsi, region)untuk membuat peraturan perundang-undangan di daerah setempat. Dalam devolusilegislatif, Dewan Rakyat yang dipilih memiliki kekuasaan untuk membuat sendiriperaturan yang berkaitan dengan daerahnya. Sedangkan dalam devolusi eksekutifsecara relatif kekuasaan yang dimiliki lemah, di mana kekuasaan untuk membuatperaturan perundang-undangan masih berada di Parlimen Nasional Inggris yangpopular disebut sebagai Westminster.

Praktek lain teori dari federalisme ideologis di negara kesatuan adalah adanyakebijakan otonomi daerah di Indonesia. Sebagaimana disebutkan dalam pendahuluandi atas, otonomi di Indonesia melahirkan ambiguistik bentuk negara dalam kaitanhubungan antara pemerintah pusat dan daerah oleh sebagian pihak.

Konsep Dasar Partai Politik Lokal untuk Indonesia

Selain adanya landasan teoritikal berupa federalisme ideologis yang diseraplndonesia pasca otonomi daerah, alasan lain dari perspektif hukum tata negara yangdapat dijadikan dasar ide pembentukan partai politik lokal ini ialah adanyapertentangan antara pengaturan dalam beberapa UU terkait sebagaimana disinggungdalam pendahuluan tulisan ini.

Pertentangan tersebut dapat dilihat dari perbedaan substansi pengaturan dalamUU No. 2 Tahun 2008 tentang Partai Politik jo UU No. 10 Tahun 2008 tentang Pemiluyang mensyaratkan Partai Politik bersifat nasional dengan ketentuan yang terdapatdalam UU No. 32 Tahun 2004 tentang Pemerintahan Daerah yang menegaskanadanya otonomi politik bagi daerah.

Partai Politik Lokal dan Otonomi Daerah 
Berdasarkan ketentuan terkait kewenangan provinsi, kabupaten/kota dalamUU No. 32 Tahun 2004, kedudukan provinsi dalam struktur pemerintahanmempunyai kewenangan untuk melakukan koordinasi, mengawasi dan membinapemerintahan kabupeten/kota di wilayahnya.Dalam konteks kewenangan otonomi itu, pemerintahan provinsi jugamempunyai kewenangan untuk menangani pelbagai urusan yang berkaitan denganurusan lintas kabupaten/kota. Berdasarkan hal itulah, konsep partai politik lokal kedepan akan lebih efektif jika diletakkan di provinsi.

Adapun partai-partai yang adadi kabupaten/kota merupakan cabang dari partai yang berpusat di provinsi tersebut.Hal ini dibuat agar, partai-partai di kabupaten/kota yang akan menempatkankadernya pada institusi legislatif dan eksekutif di kabupaten/kota dapat dimonitoroleh partai pusatnya di provinsi dan dapat menjalankan urusan otonomi secara selaras.

Partai Politik Lokal, Partai Politik Nasional, dan Pemilu

Secara yuridis ketatanegaraan, sesungguhnya telah terjadi pemisahan antarapartai politik lokal dan partai politik nasional dalam konteks hak dan kewajibanyang mereka lakukan dalam beberapa hal, Pertama, dalam hal mengajukan calonanggota parlemen (DPR/DPRD) dalam Pemilu sebagaimana diatur dalam Pasal 52UU No. 2 Tahun 2008.Kedua, dalam konteks pengawasan terhadap anggota DPR/D juga terdapatpemisahan kewenangan antara kedunya sebagaimana ditegaskan dalam UU No. 22Tahun 2003 tentang Susunan dan Kedudukan MPR, DPR, DPD dan DPRD, khususnyadalam hal pemecatan anggota DPR/D dimaksud melalui mekanisme pergantianantar waktu (PAW). Selain dua hal itu, hal yang ketiga ialah kewenangan partaiuntuk memberhentikan Ketua DPR/D yang berasal dari partainya.

Berdasarkan konstruksi hubungan antara partai politik di tingkat pusat denganpartai politik di daerah sekarang ini, maka konsep partai politik lokal ke depanhendaknya mempertegas pemisahan kewenangan yang sudah ada dalam pelbagaiperaturan perundang-undangan tersebut.

kedudukan cabang-cabang partai nasional di tingkat provinsi dan kabupatenberfungsi untuk mensosialisasikan pelbagai program kerja partai nasional ke berbagailapisan masyarakat di daerah. Khusus terkait Pemilu, cabang-cabang partai nasionaldi tingkat daerah ini sangat memegang peranan penting untuk melakukan kampanyesampai ke lapisan paling bawah. Di antara kedua cabang partai itu tidak akan terjaditumpang tindih peranan, sebab mereka dari awal telah didesain dengan peranandan lahan garap berbeda.

Relasi antar Partai Politik LokalPermasalahan lain yang mesti dibahas dalam desain partai politik lokal ini ialahhubungan antara partai politik lokal yang satu dengan yang lainnya. 
Hubungan itusangat mungkin terjadi dalam dua bentuk yaitu, hubungan positif dan negatif.Dalam konteks yang positif, hubungan antara partai politik lokal dapat hadirpada saat mereka membentuk koalisi. Sedangkan dalam konteks yang negatif,hubungan keduanya dapat saja berupa perselisihan yang secara yuridis mestidicarikan jalan keluarnya. 